\title{
FACTORS AFFECTING RETURN ON ASSETS OF US TECHNOLOGY AND FINANCIAL CORPORATIONS
}

\author{
Rudresh Pandey ${ }^{1}$, John Francis Diaz ${ }^{2 *}$ \\ ${ }^{1}$ IMBA student, International Master of Business Administration, College of Business, \\ Chung Yuan Christian University, Taoyuan City, Taiwan \\ ${ }^{2}$ Associate Professor, Department of Finance and Department of Accounting, College of Business, \\ Chung Yuan Christian University, Taoyuan City, Taiwan \\ *Corresponding author, Email: johnfrancis_diaz@yahoo.com
}

\begin{abstract}
The research examines the effect of eight firm-specific factors on the profitability, which uses return on assets (ROA) of US technology and financial firms. The study used multiple linear panel regression models, namely, ordinary least squares (OLS), fixed effects (FE) and random effects (RE) models. Empirical findings show that return on equity ratio has negative effect on ROA, while return on sales ratio has positive effect on profitability for both technology and financial firms. On one hand, current ratio has positive effect on the ROA of financial firms, while there is negative effect for technology firms. Lastly, size has a positive effect on the profitability of technology firms. This study provides renewed perspectives in creating suitable strategies to controlling factors that maximizes ROA for both US publicly-listed technology and financial companies.
\end{abstract}

Keywords: Profitability, US technology and financial firms, return on asset.

\section{Introduction}

Publicly-listed companies utilize return on assets (ROA) to measure profitability. This measures how well a firm uses its assets to generate revenue. ROA is an important indicator of asset utilization of every business organization, because asset-intensive companies tend to need more money to maintain the productive capacities of their assets. Thus, good financing choices are necessary decisions that should result in an optimal flow of revenue from existing assets. These choices represent a combination of corporate policy, and an examination of the firm's finances to maximize profit. Capital budgeting decisions are imperfect and unstable. Thus, it is essential to develop financial strategies, and coherent policies from the firm's economic and financial point of view.

Financial ratios are utilized for the purposes of discovering information of the company's internal operations. These require the calculation of the firm's capability to earn, pay its debts, and distribute earnings to shareholders. Financial ratios also assess the decision-making process, and even regulate the firm's performance (Barnes, 1987). Ratios provide a standardized method for comparing the firm's activities, and help define the firm's performance with respect to its strength or weakness.

Over time many theories of financing decisions have been developed in order to show the relevance of financial ratios and its importance in determining a firm's value. Whittington (1980) highlights the importance of financial ratios, and a firm that shows solid operating fundamentals and generate high return on its assets is certain to have successful and sustainable operations. Studies of Fabozzi (2012) and Lewellen (2004) show that financial ratio play an important role in estimating the firm's financial condition and performance; and that the ROA ratio is one of the most useful measure to assess a company's financial strength and efficiency in using its resources. The authors also argued that the ratio is important for management to measure its asset performance against its planned business goals, and against market competitors.

This study uses ROA as a proxy for profitability of US technology and financial publicly-listed companies. The US has the largest technology and financial market in the world, and have witnessed a significant growth during the past two decades. These sectors are not only a major contributor to the gross domestic product (GDP), but also play an important role as a growth engine to the economy. In 2018, the Information Technology (IT) sector created approximately 200,000 new jobs, and employed an estimated 11 million workers. In terms of GDP, it is largest contributor valuing at USD1.67 trillion.

The US Bureau of Labor Statistics projects that the IT-related jobs will rise to 626,000 by 2026 . New industries such as cloud based services and artificial intelligence (AI) will play a major role in transform- 
ing technological change to creativity and productivity. The studies of Jorgenson, Ho, and Samuels (2011) and Stiroh (2002) show that a wide resurgence of inventiveness and efficiency emanating from the IT industry have contributed a great deal to the economy. The Financial sector, on the other hand, are made of four diverse divisions, which include insurance carriers, credit intermediation, and securities. The sector is another huge GDP value contributor in the US with an additional contributed value of USD1.1 trillion, which accounts to $8 \%$ of the total GDP. The US has more than 5,800 credit unions and 5,900 banks. Though a comparatively weak economic recovery since the financial crisis of 2008 , the banking system has demonstrated flexibility, improving liquidity standards, increasing capital, improving loan portfolio quality, and implementing better risk management practices.

These two sectors help in the acceleration of US exports, and is also estimated that they directly employ more than five million people, which is equal to around $4 \%$ of the total employment of the US economy. The study is motivated by the constantly growing US Financial and Technology sectors, and the potential of the companies to contribute to the economy. Another motivation is the limited empirical literature in determining the factors that affect the ROA of these publicly-listed firms. This paper plans to contribute to the empirical findings regarding finance and technology sectors of the US. This paper contributes to the literature by identifying determinants of ROA using three regression models: Ordinary Least Squares (OLS) model, Fixed Effect (FE) model, and Random Effect (RE) model. The study will also try to improve its contributions by attempting to divide the samples into three groups, namely, a) all US publicly-listed companies; b) financial firms; and c) technology companies.

The broader objective of this research is to identify significant factors affecting the ROA of US Financial and Technology companies; and the three specific objectives are:

a. to identify significant positive and negative effects of company-specific factors on ROA;

b. to determine which firm-specific factors have stronger effect on profitability based on the coefficients' outcome; and

c. to examine if there are differences on the significant factors determining the profitability of technology and financial companies based on market capitalization.

This study's objectives contribute to the body of empirical evidence in determining financial factors that management can utilize to better understand changes in a company's ROA and how to utilize assets better. Findings can also benefit managers of publicly-listed companies in controlling ROA in relation to the specific financial variables under study. Findings of the study contributes in improving corporate strategies to minimize losses and maximize gains by examining corporate variables considered in this study.

Previous studies provide theoretical frameworks and empirical evidences revealing the effect of different factors profitability. A fair number of researchers have worked on theories and financial ratios in order to examine its role in determining returns in a company.

\section{Theories on Capital Structure in Relation to ROA}

According to Trade-off theory, company managers believe that they can find an optimal capital structure to maximize the returns from the firm's assets. An optimal leverage is a trade-off between advantage and cost of debt (Modigliani \& Miller, 1963). Advantage of debt is due to tax deductible interest payment, while the potential cost of debt includes bankruptcy cost and agency cost between owners and creditors. However, according to Modigliani and Miller (1963), since firms can benefit from corporate taxes, they tend to employ as much debt as possible. The Pecking order theory addresses problems associated with information asymmetry on investment and financing decisions of companies. This theory was the focus of Myers (1984), and Myers and Majluf (1984) previous studies, and was based on the belief that when firms issue new equity, it sends a negative signal to investors that companies' stocks are overvalued which encourages managers to issue new shares.

Agency cost theory discusses the conflicts between interest of owners and managers. Owners of companies in the form of shareholders hire managers to help them operate firms and expect that managers increase value of the firms they are managing. Jensen \& Meckling (1976) earlier pointed out these kinds of conflicts: managers vs. shareholders, and debtholders vs shareholders. They also suggested that debt can help to solve the agency cost between managers and stockholders. Market timing theory also explains the effect of asymmetric information on capital structure. The theory suggests that firms try to issue new stocks when stock price is increasing and repurchase stocks when stock price is low. This theory was introduced by Myers and Majluf (1984). According to this theory, executives believe that they can enter the market right in time to maximize value of firms. 


\section{Factors Affecting Return on Asset (ROA)}

Beaver (1966) utilized financial ratios to predict corporate failure, and found significant evidence that ratios can possibly detect firm performance. In a more recent study, Sufian and Habibullah (2009) examined the performance of 37 Bangladeshi Commercial banks in relation to equity, assets and interests from 1997 to 2004. The empirical findings suggested that size has a negative effect on the return on average equity, while the opposite is true for the return on average assets and net interest margins. On one hand, Batchimeg (2017) investigated the effects of profitability, growth, liquidity and capital structure on the financial performance of six major sectors in Mongolia, and evaluated if there is any difference related with its sector. The study found that ROA has more determinants than ROE and return on sales (ROS). In a related study, Tong and Diaz (2017) investigated the important factors affecting capital structure decisions in Vietnamese Commercial Banks, and found that Vietnamese bank's asset size positively affects leverage, which means that the larger the asset of the bank, the more debt is incurred.

Anarfo (2015) studied factors like short-term debt, long-term debt and total debt ratios of SubSaharan African banks. Their findings revealed that ROA is negatively affected by leverage, because most of banks in the study prefer internal financing to reduce information asymmetry. Also, Feng and Guo (2015) analyzed the effect of capital structure on the financial performance of real estate listed companies in Shanghai, and showed that the high debt ratio negatively affects financial performance. Furthermore, Diaz and Hindro (2017) analyzed the profitability of Indonesian publicly-listed real estate companies, and found that the number of days account receivable has negative effect on ROA for large and small companies, but it has no effect on mediumsized firms.

On one hand, Vătavu (2015) investigated the capital structure and its effect on the financial performance of Romanian companies. The study found that the capital structure determinants such as business risk, and tangibility have a negative effect on ROA, taxation level, on one hand, has a positive effect. Ebaid (2009) used three of accounting-based measures of financial performance to affect ROA based on a sample of non-financial Egyptian publicly-listed firms from 1997 to 2005 . The study found that capital structure affects negatively the firm's performance determined by ROA. Gocmen and Sahin (2014) studied the capital structure determinants of 30 Turkish banks during the global financial crisis in 2008. The paper found that ROA is negatively affected by short-term and long-term debts. The study also observed that banks used more long-term debts after the crisis due to the increase in demands.

\section{Variable Description and Hypotheses}

From the empirical studies investigating factors influencing ROA of several economies, this research considers eight factors that may affect the ROA of US technology and financial firms. The definitions and hypotheses of each variable are discussed below while formulas, and expected outcome of the study are summarized in Table 1.

\section{Return on Asset (ROA)}

ROA is a profitability ratio calculated by dividing net income to total assets. This ratio shows a firm's financial performance by measuring how efficiently a firm uses its assets to produce sales over a year. ROA reflects the management's ability to generate profit from the assets of the firm (Aissa \& Goaied, 2016). In the previous studies, Vătavu (2015), Enqvist, Graham, and Nikkinen, (2014), and San and Heng (2013) used ROA as a proxy to analyze firm's profitability. Hence, ROA will be used to measure a firm's overall profitability, and will be the dependent variable for the purpose of this research of the following eight independent variables. According to the Bankruptcy cost theory, firms with large asset base tend to gain more liabilities than small ones, because of having easier access to capital markets, as well as good relationship with creditors (Vătavu, 2015).

\section{Return on Equity (ROE)}

Return on equity (ROE) is a financial performance measure calculated by dividing net income by outstanding shares, and is considered as a measure of the earnings performance of a firm. The ROE tells shareholders how their money is used effectively. Based on the Agency cost theory, Jensen (1986) and Williamson (1988) stated that profitable firms usually have higher free cash flow, which encourages managers to invest more frequently. The studies of Shubita and Alsawalhah (2012), and Şamiloğlu, Öztop, and Kahraman (2017) argued that there is direct connection between the ROE and profitability. Therefore, this study suggests the alternative hypothesis below: $H_{l}$ : ROE has positive effect on profitability.

\section{Return on Sales (ROS)}

Return on sales is a profitability ratio computed by dividing net profits to total assets. According to the studies of Herciu, Ogrean, and Belascu (2011), Sukpanich (2007), and Tangen (2003) the effect of return 
on sales on profitability is positive, which means firm is able to generate profits from its sales. According to the Agency cost theory, companies with higher free cash flow coming from sales encourages managers to invest. An increasing ROS indicate that the firm is becoming more efficient, while a decreasing ratio may be a sign of financial weakness. For the purposes of this study, we'll be going with the alternative hypothesis below:

$\mathrm{H}_{2}$ : ROS of the firm has positive effect on profitability.

\section{Current Ratio (CR)}

Current ratio is a liquidity ratio calculated by dividing current assets to current liabilities. It indicates the firm's ability to pay its short-term obligations due within one year. Studies of Panigrahi (2013), Saleem and Rehman (2011), Bolek and Wili'nski (2012) showed that current ratio negatively affects profitability. However, all the studies indicated that short-term liabilities and assets are important part of total assets and needed to be analyzed. Babalola and Abiola (2013) found that high ratio is a sign of unsystematic operation of funds. For the purposes of this study, we'll be going with the alternative hypothesis below:

$H_{3}$ : Current ratio of the firm has positive effect on profitability.

\section{Long Term Debt ratio (LTDR)}

Long-term debt ratio measures firm's ability to pay outstanding loans due over a year. It is measured by dividing long-term debt over total assets. The effect of risk on leverage is explained by the Bankruptcy cost theory. An earlier study of Titman and Wessels (1988) explained that less stable earnings firms bear higher bankruptcy cost; thus, they refuse to add more debt. The studies of Badar and Saeed (2013) and Ramadan (2013) show that firms opting for long-term debt in place of short-term debt have better performance. On the other hand, Akintoye (2008) and Abor (2007) argued that long-term debt does not correspond to increase in firm's profit. Based on the Bankruptcy cost theory, companies with large assets tend to acquire more liabilities, and uses this leverage to gain more profits. For the purposes of this study, we'll be going with the alternative hypothesis below:

$H_{4}$ : LTD of the firm has positive effect on profitability.

\section{Debt Ratio (TD)}

Total debt ratio shows the part of a firm's assets that are financed using liabilities. The ratio is computed by dividing total debt over total assets. Several studies like Handoo and Sharma (2014), Kebewar (2012) and Deloof (2003) have showed that high debt ratio do not have effect on the firm's profitability. The earlier study of Toy, Stonehill, Remmers, Wright, and Beekhuisen (1974) found that higher earnings risks are associated with higher debt ratio, which was corroborated by (Ofek, 1993) suggested that highly indebted firms are more prone to failure. According to the Bankruptcy cost theory, companies with large assets tend to highly leveraged, which sometimes lead to failure if debt is not managed properly, but if taken cared well, debt produces higher returns on equity. For the purposes of this study, the study will be going with the alternative hypothesis below:

$H_{5}$ : TDR of the firm has positive effect on profitability.

\section{Size (SZ)}

The total asset represents the size of the firm. Based on the Bankruptcy cost theory, companies with large asset base tend to gain more liabilities than small ones (Vătavu, 2015). According to the studies of García-Teruel and Martínez-Solano (2007), Deloof (2003) and Lazaridis and Tryfonidis (2006), the effect of firm size on profitability is positive, which means that the bigger the firm, the higher is the profitability than smaller firms. However, Enqvist et al. (2014) and Hall and Weiss (1967) observe that firm size has a negative effect on profitability. For the purposes of this study, we'll be going with the alternative hypothesis below:

$H_{6}$ : Size of the company has positive effect on profitability.

\section{Tangibility (TANG)}

Tangibility refers to the fixed assets in a specific accounting year of the firm. It is calculated by dividing fixed assets to total assets. According to the previous literature, there are two conflicting effects of tangibility on firm's performance. Himmelberg, Hubbard, and Palia (1999) found that tangible assets are easy to manage and a very reliable source for collateral. However, Bhutta and Hasan (2013) and Margaritis and Psillaki (2007) found that firms with high level of tangible assets tend to be less profitable because they have low R\&D activities, and lower long-term investment. This is also confirmed by Kebewar (2012), Rao, Al-Yahyaee, and Syed, (2007), Hammes and Chen (2004), explaining that tangibility negatively affects profitability. Therefore, this study suggests the alternative hypothesis below:

$H_{7}$ : Tangibility has negative effect on profitability. 


\section{Research Method}

\section{Data and Sample Selection}

This study collects financial statements, which includes balance sheet, income statement, and cash flow of the top US Financial and Technology companies listed in the New York Stock Exchange from 2014-2017. Data was obtained from the Yahoo! Finance website under the Financials tab. Financial ratios were manually computed by the authors using Microsoft Excel. The complete list of companies under study can be found on Appendix List.

\section{Methodology}

This study examines eight firm-specific factors that determine the profitability of US Technology and Financial firms. Those factors are: return on sales (ROS), short term debt ratio (STDR), long term debt ratio (LTDR), total debt ratio (TDR), company size (SIZE), active structure (TANG), current ratio (CR), return on equity (ROE) and the general null and alternative hypotheses are:

- $H_{0}$ : Independent variables have no explanatory power on the ROA of US Financial and Technology companies $(\beta \mathrm{i}=0)$

- $H_{1}$ : Independent variables have explanatory power on the ROA of US Financial and Technology companies $(\beta \mathrm{i} \neq 0)$

The hypotheses testing use multiple regression, and the estimation of regression model is as follows: $R O A=\beta O+\beta 1 R O S i, t+\beta 2 C R i, t+\beta 3 S T D i, t+$ $\beta 4 L T D i, t+\beta 5 T D i, t+\beta 6 T A N G i, t+$ $\beta 7 S I Z E i, t+\beta 8 R O E i, t+\varepsilon i, t$

Results on the coefficients from the regression are likely to show whether a positive or negative effect exist between the independent and dependent variables. Also, the significance of the coefficients will be analyzed by comparing the $p$ values with $\alpha=$ $10 \%, 5 \%$, and $1 \%$ levels of significance.

Variables used will be initially examined using the multicollinearity test to check whether two or more explanatory variables are highly linearly related. In detecting the multicollinearity problem, the following will be observed:

a) if the value of $R^{2}$ is high, and there are few significant $t$ ratios; and

b) if the correlation from the Pearson correlation coefficient matrix is higher than 0.8 .

Two classes of estimator approaches are used in this study to determine which model fits the panel data. First, with the fixed effects model, the relation between error term and variables is assumed and then the specific effect of time - invariant features is terminated. It aims at assigning the net effect of the explanatory variables and also discovering the uniqueness of these characteristics. Second, the model of random effects assumes that the variations are random and uncorrelated to the explanatory variables across the entities. The inclusion of time-invariant variables is also considered in this model. This study will be utilizing the lowest value of the Schwarz criterion (Schwarz, 1978) to select the best fitting model.

\section{Empirical Results}

The paper used Multicollinearity test to examine whether two or more independent variables are linearly related. Multicollinearity exists if the coefficient between two variables exceeds 0.8. Initial test results found that short-term debt (STD) and longterm debt (LTD) are linearly related with their coefficient exceeding beyond 0.8 . The study removed STD, because LTD is closer to the significance level. By observing the Pearson correlation coefficient matrix, Table 1 shows that there is no relationship coefficient exceeding 0.8 , which means that multicollinearity problem does not exist.

Table 2 presents comparison results of the OLS, $\mathrm{FE}$, and RE models in determining significant factors that affect the ROA of US Technology and Financial publicly-listed companies. Based on the lowest values of the Schwarz criterion, the RE Model is preferred over the FE model. RE and OLS models both have the lowest the Schwarz criterion and can best represent the relationship of the independent variables to the ROA. The significant results on the regression analyses of the OLS, FE and RE models, found that ROE has a negative relationship with ROA of US publicly-listed firms under study. This means that lower allocation is given to the assets of the firm if there are higher returns given to investors. This result is consistent with the alternative hypothesis, and with the papers of Samiloglu et al. (2017) and Shubita and Alsawalhah (2012).

These studies explained that as the returns given to shareholders become higher, the less is allocated for capital expenditures. Therefore, this paper recommends that the publicly-listed companies prioritize asset expansion, but still try to provide acceptable returns to equity holders.

The regression models also found ROS has positive effect on profitability of US publicly-listed firms, which implies that the higher the ROS, the better is the returns coming from its total assets. 
Table 1

Correlation Matrix of the Eight Firm-specific Independent Variables

\begin{tabular}{|c|c|c|c|c|c|c|c|c|}
\hline Category & Variables & ROE & ROS & LIQ & LTD & TD & TANG & SIZE \\
\hline \multirow{7}{*}{ 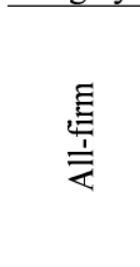 } & ROE & 1.00 & -0.150 & -0.108 & 0.430 & 0.012 & -0.251 & 0.102 \\
\hline & ROS & & 1.000 & -0.071 & -0.078 & 0.066 & -0.065 & -0.035 \\
\hline & LIQ & & & 1.000 & -0.040 & 0.336 & -0.179 & -0.032 \\
\hline & LTD & & & & 1.000 & -0.312 & 0.085 & -0.037 \\
\hline & TD & & & & & 1.000 & 0.457 & 0.089 \\
\hline & TANG & & & & & & 1.000 & -0.072 \\
\hline & SIZE & & & & & & & 1.000 \\
\hline \multirow{7}{*}{ 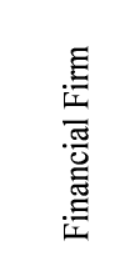 } & ROE & 1.000 & 0.349 & 0.218 & 0.693 & 0.009 & -0.243 & -0.643 \\
\hline & ROS & & 1.000 & -0.383 & 0.068 & 0.211 & 0.474 & 0.380 \\
\hline & LIQ & & & 1.000 & 0.350 & -0.790 & -0.746 & -0.548 \\
\hline & LTD & & & & 1.000 & 0.086 & -0.380 & -0.710 \\
\hline & TD & & & & & 1.000 & 0.370 & 0.112 \\
\hline & TANG & & & & & & 1.000 & 0.647 \\
\hline & SIZE & & & & & & & 1.000 \\
\hline \multirow{7}{*}{ 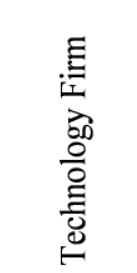 } & ROE & 1.000 & -0.166 & -0.333 & 0.322 & 0.446 & 0.105 & 0.059 \\
\hline & ROS & & 1.000 & -0.076 & -0.132 & 0.154 & 0.024 & -0.048 \\
\hline & LIQ & & & 1.000 & -0.325 & -0.537 & -0.333 & -0.077 \\
\hline & LTD & & & & 1.000 & 0.461 & -0.178 & 0.178 \\
\hline & TD & & & & & 1.000 & 0.074 & 0.247 \\
\hline & TANG & & & & & & 1.000 & -0.161 \\
\hline & SIZE & & & & & & & 1.000 \\
\hline
\end{tabular}

This finding is consistent with the alternative hypothesis, and the earlier findings of Herciu et al. (2011), Sukpanich (2007) and Tangen (2003) who reported that a high return on sales is significant and positively affects profitability. Therefore, this paper suggests that US publicly-listed firms should continuously improve their products and services, and develop their marketing efforts to create sales.

Another significant finding is that LTD has negative effect on ROA of US publicly-listed firms. This finding means that firms are using relatively lower long-term debt to finance their operations. This result does not support the alternative hypothesis of the study, and the findings of Habib, Khan, and Wazir (2016), Akintoye (2008) and Abor (2007) who all found that LTD has negative effect on profitability. The paper suggests that US publicly-listed firms should maintain a healthy level of LTD ratio, because its maximizes their leverage compared to competitors.

Lastly, TD has a positive effect on profitability of US publicly-listed firms. This result implies that an increase in the total debt relates to a higher ROA. This result is consistent with the alternative hypothesis of the study, and the findings of Gill, Biger, and Mathur (2011) and Margaritis and Psillaki (2007). Thus, it is suggested that US publicly-listed companies diversify their financing options, and must balance a healthy percentage of debt and equity.

Based on the OLS, FE and RE models, tangibility negatively affects profitability of US publiclylisted firms. This implies that higher tangible assets are a detriment to the profitability of publicly-listed companies, and investments in fixed assets have a negative effect on their financial performance. This result is consistent with the alternative hypothesis of the study, and with the initial findings of (Kebewar, 2012) and (Rao et al., 2007). Therefore, this paper suggests that US publicly-listed companies should minimize the acquisition unproductive property, plant and equipment, because this lead to more costs instead of revenues in the future.

Table 3 presents comparison results of the OLS, $\mathrm{FE}$, and RE models in determining the significant factors that affect the ROA of US publicly-listed Financial companies. According to the Schwarz criterion, the RE Model is again preferred over the FE model. RE and OLS models both have the lowest the Schwarz criterion. Looking at the regression analyses of the OLS, FE and RE models, ROE is also found to have a negative effect on ROA of US Financial firms, which is consistent with the results in Table 2. Therefore, this paper recommends that financial firms provide acceptable returns to shareholders, but still should prioritize capital expenditures to sustain profitable operations in the future.

Furthermore, the study found that ROS also has positive effect on ROA of US Financial firms, which implies that the higher the ROS. This study suggests that US financial firms should consistently offer improvements in their financial products and services, and develop their marketing efforts to create sales and sustain their competitiveness. 
Table 2

Multiple Regression Result for US Technology and Financial Firms

\begin{tabular}{|c|c|c|c|}
\hline Firm-specific variables & OLS & $\mathrm{FE}$ & $\mathrm{RE}$ \\
\hline \multicolumn{4}{|l|}{$\mathrm{ROE}$} \\
\hline coefficient & $-4.679 * * *$ & $-4.679 * * *$ & $-4.679 * * *$ \\
\hline standard error & 1.465 & 1.471 & 1.465 \\
\hline p-value & $(0.001)$ & $(0.001)$ & $(0.001)$ \\
\hline \multicolumn{4}{|l|}{ ROS } \\
\hline coefficient & $0.363 *$ & $0.363 *$ & $0.363 *$ \\
\hline standard error & 0.213 & 0.213 & 0.213 \\
\hline p-value & $(0.091)$ & $(0.093)$ & (0.089) \\
\hline \multicolumn{4}{|l|}{ LIQ } \\
\hline Coefficient & -0.088 & -0.088 & -0.088 \\
\hline standard error & 0.233 & 0.234 & 0.233 \\
\hline$p$-value & $(0.704)$ & $(0.705)$ & $(0.703)$ \\
\hline \multicolumn{4}{|l|}{ LTD } \\
\hline coefficient & $-11.151 * * *$ & $-11.151 * * *$ & -11.151 \\
\hline standard error & 2.737 & 2.749 & $* * *$ \\
\hline p-value & $(0.001)$ & $(0.001)$ & $\begin{array}{l}2.737 \\
(0.001)\end{array}$ \\
\hline \multicolumn{4}{|l|}{ TD } \\
\hline coefficient & $10.446 * * *$ & $10.446 * * *$ & $10.446 * * *$ \\
\hline standard error & 1.536 & 1.543 & 1.536 \\
\hline p-value & $(0.000)$ & $(0.000)$ & $(0.000)$ \\
\hline \multicolumn{4}{|l|}{ TANG } \\
\hline coefficient & $-0.261 * *$ & $-0.261 * *$ & $-0.261 * *$ \\
\hline standard error & 0.129 & 0.129 & 0.129 \\
\hline$p$-value & $(0.045)$ & $(0.046)$ & $(0.043)$ \\
\hline \multicolumn{4}{|l|}{ SIZE } \\
\hline coefficient & -0.002 & -0.002 & -0.002 \\
\hline standard error & 0.002 & 0.002 & 0.002 \\
\hline p-value & $(0.366)$ & (0.369) & $(0.365)$ \\
\hline \multicolumn{4}{|l|}{ Constant } \\
\hline coefficient & -1.997 & -1.997 & -1.997 \\
\hline standard error & 1.410 & 1.416 & 1.410 \\
\hline p-value & (0.159) & $(0.161)$ & $(0.156)$ \\
\hline$R$-squared & 0.503 & 0.503 & \\
\hline Log-likelihood & -282.301 & -282.301 & -282.301 \\
\hline Schwarz criterion & 603.035 & 607.840 & 603.035 \\
\hline
\end{tabular}

Note: *,** and ***are significance at the 10, 5 and $1 \%$ levels.

For the effect of liquidity proxied by the $\mathrm{CR}$ on ROA, the OLS, FE and RE models found that CR positively affects profitability of US Financial firms. This corresponds to the alternative hypothesis of the study, and to the paper of Enqvist et al. (2014). The research explained that the larger the ratio, the more capable the Financial company is. The firm can also cover current liabilities, which is necessary for the smoother running of daily operations without pressure from lenders. Higher current assets will benefit the company in being more flexible and in getting more investments in the future, further increasing profitability. It is suggested that US Financial companies maintain a higher CR by keeping assets revolving, particularly account receivables and inventories and paying off liabilities, especially those with higher interest rates whenever necessary. Another finding consistent with Table 2 is the negative effect of LTD on profitability of US Financial firms. The paper recommends that US Financial firms should minimize LTD ratio, if it doesn't maximize the earning potential of leveraging. Furthermore, the three models show that TD has a positive effect on the ROA of US Financial companies. Lastly, tangibility negatively affects profitability of US Financial firms.

Table 3

Multiple Regression Result for Financial Firms

\begin{tabular}{|c|c|c|c|}
\hline Firm-specific variables & OLS & $\mathrm{FE}$ & $\mathrm{RE}$ \\
\hline \multicolumn{4}{|l|}{$\overline{\mathrm{ROE}}$} \\
\hline coefficient & $-23.722 *$ & $-23.722 *$ & $-23.722 * *$ \\
\hline standard error & 11.977 & 12.098 & 11.977 \\
\hline$p$-value & $(0.053)$ & 0.055 & 0.047 \\
\hline \multicolumn{4}{|l|}{ ROS } \\
\hline coefficient & $19.047 * *$ & $19.047 * *$ & $19.047 * *$ \\
\hline standard error & 8.157 & 8.240 & 8.157 \\
\hline p-value & $(0.023)$ & 0.025 & 0.019 \\
\hline \multicolumn{4}{|l|}{ LIQ } \\
\hline Coefficient & $3.411 * * *$ & $3.411 * * *$ & $3.411 * * *$ \\
\hline standard error & 1.159 & 1.171 & 1.159 \\
\hline p-value & $(0.004)$ & $(0.005)$ & $(0.003)$ \\
\hline \multicolumn{4}{|l|}{ LTD } \\
\hline coefficient & $-23.269 * * *$ & $-23.269 * * *$ & $-23.269 * * *$ \\
\hline standard error & 7.061 & 7.133 & 7.061 \\
\hline$p$-value & $(0.001)$ & $(0.002)$ & $(0.001)$ \\
\hline \multicolumn{4}{|l|}{ TD } \\
\hline coefficient & $36.955 * * *$ & $36.955 * * *$ & $36.955 * * *$ \\
\hline standard error & 6.206 & 6.269 & 6.206 \\
\hline$p$-value & $(0.000)$ & $(0.000)$ & $(0.000)$ \\
\hline \multicolumn{4}{|l|}{ TANG } \\
\hline coefficient & $-0.590 * * *$ & $-0.590 * * *$ & $-0.590 * * *$ \\
\hline standard error & 0.196 & 0.198 & 0.196 \\
\hline$p$-value & $(0.004)$ & $(0.004)$ & $(0.002)$ \\
\hline \multicolumn{4}{|l|}{ SIZE } \\
\hline coefficient & 2.463 & 2.463 & 2.463 \\
\hline standard error & 2.390 & 2.414 & 2.390 \\
\hline p-value & $(0.307)$ & $(0.312)$ & $(0.302)$ \\
\hline \multicolumn{4}{|l|}{ Constant } \\
\hline coefficient & $-49.376 * *$ & $-49.376 *$ & $-49.376 * *$ \\
\hline standard error & 24.339 & 24.586 & 24.339 \\
\hline p-value & $(0.047)$ & $(0.050)$ & $(0.042)$ \\
\hline$R$-squared & 0.717 & 0.717 & \\
\hline Log-likelihood & -125.093 & -125.093 & -125.093 \\
\hline Schwarz criterion & 282.670 & 286.730 & 282.670 \\
\hline
\end{tabular}

Table 4 presents comparison results of the OLS, $\mathrm{FE}$, and RE models in determining the significant factors that affect the ROA of US publicly-listed companies. Based on the Schwarz criterion, the RE Model is again preferred over the FE model. RE and OLS models can best represent the relationship of the independent variables to the ROA, because of having both the lowest Schwarz criterion. Based on the regression analyses of the OLS, FE and RE models, ROE and ROS have similar positive effects on profitability, which is similar to the earlier findings. 
For the effect of CR on ROA, the OLS, FE and RE models found that CR negatively affects profitability of the US Technology firms. This means that as the main components of CR such as cash, receivables accounts, and inventory increase, profitability of the firm diminishes. The result does not support the alternative hypothesis of a positive effect, and contradicts the explanation of Irawan and Faturohman (2015), who found significant and positive effect of CR on profitability measured by ROA. Nevertheless, this study still suggests that technology firm in US should maintain a certain healthy level of CR comparable to the industry benchmark to maintain liquidity. Thus, with a healthy level of CR, a technology firm has a solid financial foundation that will help them to perform better in times of financial turbulence.

Based on the three models applied, LTD and TD has the same negative and positive effects, respectively on profitability of the US Technology firms, which are consistent with the results of Tables 2 and 3. What's unique in the findings is that tangibility positively affects profitability of US Technology firms, which implies that higher tangible assets are able to generate higher profitability, and investments in fixed assets have a positive effect on their financial performance. However, this finding is not actually consistent with the alternative hypothesis of the study, and the initial findings of Kebewar (2012) and Rao et al. (2007). One possible explanation is that tangible assets can serve as a collateral for bank loans, which can benefit technology firms in borrowing needed funds, especially for $\mathrm{R} \& \mathrm{D}$, or to expand their operations Hammes and Chen (2004). Therefore, this paper recommends that US Technology companies should maintain huge amounts of tangible fixed assets to the point where they are able to maximize their productivity. It is further suggested that US Technology companies minimize the acquisition unproductive property, plant and equipment, because maintaining them lead to more expenditures.

The regression analyses of the OLS, FE and RE models found that SZ positively affects profitability of the US technology firms, which implies that large firms are able to generate more profit, the larger the firm gets. This corresponds to the alternative hypothesis, and to the studies of Lun and Quaddus (2011), García-Teruel and Martínez-Solano (2007), Lazaridis and Tryfonidis (2006), and Deloof (2003), who found positive effect of size on profitability. These studies stated that growing assets will lead to higher profitability as total asset can elevate the operations. Thus, it is suggested that huge US firms Technology benefit from the broader extent of operations and a wider customer base, which translates to sales and profitability.

\section{Table 4}

Multiple Regression Result for Technology Firms

\begin{tabular}{|c|c|c|c|}
\hline Firm-specific variables & OLS & $\mathrm{FE}$ & $\mathrm{RE}$ \\
\hline \multicolumn{4}{|l|}{$\mathrm{ROE}$} \\
\hline coefficient & $-0.153 * * *$ & $-0.153 * * *$ & $-0.153 * * *$ \\
\hline standard error & 0.047 & 0.047 & 0.047 \\
\hline p-value & $(0.002)$ & $(0.002)$ & $(0.002)$ \\
\hline \multicolumn{4}{|l|}{ ROS } \\
\hline coefficient & $1.651 * * *$ & $1.651 * * *$ & $1.651 * * *$ \\
\hline standard error & 0.010 & 0.010 & 0.010 \\
\hline p-value & $(0.000)$ & $(0.000)$ & $(0.000)$ \\
\hline \multicolumn{4}{|l|}{ LIQ } \\
\hline Coefficient & $-0.026 * * *$ & $-0.026 * * *$ & $-0.026 * * *$ \\
\hline standard error & 0.007 & 0.007 & 0.007 \\
\hline p-value & $(0.000)$ & $(0.000)$ & $(0.000)$ \\
\hline \multicolumn{4}{|l|}{ LTD } \\
\hline coefficient & $-0.342 * * *$ & $-0.342 * * *$ & $-0.342 * * *$ \\
\hline standard error & 0.100 & 0.101 & 0.101 \\
\hline$p$-value & $(0.001)$ & (0.001) & $(0.001)$ \\
\hline \multicolumn{4}{|l|}{$\mathrm{TD}$} \\
\hline coefficient & $0.200 * * *$ & $0.200 * * *$ & $0.200 * * *$ \\
\hline standard error & 0.066 & 0.067 & 0.067 \\
\hline p-value & $(0.003)$ & $(0.004)$ & $(0.004)$ \\
\hline \multicolumn{4}{|l|}{ TANG } \\
\hline coefficient & $0.223 * * *$ & $0.223 * * *$ & $0.223 * * *$ \\
\hline standard error & 0.050 & 0.051 & 0.051 \\
\hline p-value & $(0.000)$ & $(0.000)$ & $(0.000)$ \\
\hline \multicolumn{4}{|l|}{ SIZE } \\
\hline coefficient & $0.000 * *$ & $0.000 * *$ & $0.000 * *$ \\
\hline standard error & 6.736 & 6.799 & 6.799 \\
\hline p-value & $(0.045)$ & $(0.048)$ & $(0.048)$ \\
\hline \multicolumn{4}{|l|}{ Constant } \\
\hline coefficient & $-0.173 * * *$ & $-0.173 * * *$ & $-0.173 * * *$ \\
\hline standard error & 0.051 & 0.051 & 0.051 \\
\hline p-value & $(0.001)$ & $(0.001)$ & $(0.001)$ \\
\hline$R$-squared & 0.998 & 0.998 & \\
\hline Log-likelihood & 80.958 & 80.958 & 80.958 \\
\hline Schwarz criterion & -128.901 & -124.774 & -128.901 \\
\hline
\end{tabular}

\section{Conclusions and Limitations}

The paper examined the effect of eight firmspecific factors on the ROA of US technology and financial firms. Results showed that ROE ratio negatively affects ROA, while ROS ratio has positive effect on profitability for both technology and financial firms. CR has a positive effect on profitability of the US publicly-listed financial firms, while there is negative effect for technology firms. On the other hand, LTD has negative effect, while TD has positive effect on the profitability of both US publicly-listed firms. These findings showed that firms in US are using high level of debt to finance their operations and they are able to generate profits from the borrowings. However, this study suggested that technology and financial firms should not exceed 
debt ratio above the industry average. TANG has a negative effect on profitability of financial firms, while the opposite is true for technology firms. This study posited that tangible assets benefit technology firms, because they can serve as a collateral for bank loans. This helps the technology firms to expand their operations, but financial firms should avoid the acquisitions of unproductive assets. Lastly, SZ has a positive effect on profitability for technology firms. This finding suggested that variable size is intuitive for technology firms because growing assets can increase the operations which will lead to increase in profitability. Findings of this research are robust in the use of three panel regression models, and can help investor have a general perspective regarding determinants of ROA in the expanding US market. This study also provides renewed perspectives in creating suitable strategies to controlling factors that maximizes profitability for both US publicly-listed technology and financial companies.

The above findings provided a good perspective in examining internal factors that affect profitability, using ROA of US Technology and Financial firms. Further studies are suggested to examine similar variables using other quantitative methods (e.g., Grey Relational Analysis) to determine factors based on company size or net income, for example. Qualitative type of research can also be considered for future studies to personally better know how managers observe and control particular variables (e.g., number of days' account payable and tangibility) in increasing profit and adding value of the firm. Another limitation of this research is that it did not consider external or macroeconomic factors (i.e., economic status, interest rates, government regulations and stock market conditions) that are also important in determining profitability of publicly-listed companies. Future studies can further consider these factors, and can also extend the data to cover private companies, because the study is only limited to publicly-listed companies. Future research can also extend the data to cover other publicly-listed companies (e.g., mining and transportation companies), and even compare these data with other developing countries' findings.

\section{References}

Abor, J. (2007). Debt policy and performance of SMEs: Evidence from Ghanaian and South African firms. Journal of Risk Finance, 8(4), 364-379.

Aissa, S. B., \& Goaied, M. (2016). Determinants of Tunisian hotel profitability: The role of managerial efficiency. Tourism Management, 52, 478-487.
Akintoye, I. R. (2008). Effect of capital structure on firms' performance: The Nigerian experience. European Journal of Economics, Finance and Administrative Sciences, 10(1), 233-243.

Anarfo, E. B. (2015). Determinants of capital structure of banks: Evidence from Sub-Sahara Africa. Asian Economic and Financial Review, 5(4), 624-640.

Babalola, Y., \& Abiola, F. (2013). Financial ratio analysis of firms: A tool for decision making. International Journal of Management Sciences, 1(4), 132-137.

Badar, R., \& Saeed, A. (2013). Impact of capital structure on performance empirical evidence from sugar sector of Pakistan. European Journal of Business and Management, 5(5), 78-86.

Barnes, P. (1987). The analysis and use of financial ratios: A review article. Journal of Business Finance \& Accounting, 14(4), 449-461.

Batchimeg, B. (2017). Financial performance determinants of organizations: The case of Mongolian companies. Journal of Competitiveness, 9(3), 22-33.

Beaver, W. H. (1966). Financial ratios as predictors of failure. Journal of Accounting Research, 4, 71111.

Bhutta, N. T., \& Hasan, A. (2013). Impact of firm specific factors on profitability of firms in food sector. Open Journal of Accounting, 2, 19-25.

Bolek, M., \& Wili'nski, W. (2012). The effect of liquidity on profitability of Polish construction sector companies. E-Finanse: Financial Internet Quarterly, 8(1), 38-52.

Deloof, M. (2003). Does working capital management affect profitability of Belgian firms? Journal of Business Finance \& Accounting, 30(3-4), 573-588.

Diaz, J. F. T., \& Hindro, M. C. T. (2017). Factors affecting the profitability of Indonesian real estate publicly-listed companies. Asian Journal of Finance and Accounting, 9(1), 396-428.

Ebaid, I. E. (2009). The impact of capital-structure choice on firm performance: Empirical evidence from Egypt. Journal of Risk Finance, 10(5), 477-487.

Enqvist, J., Graham, M., \& Nikkinen, J. (2014). The impact of working capital management on firm profitability in different business cycles: Evidence from Finland. Research in International Business and Finance, 32, 36-49.

Fabozzi, F. J. (2012). Encyclopedia of financial models. Volume 2. Hoboken, NJ: John Wiley \& Sons, Inc. 
Feng, Y., \& Guo, Y. (2015). The relationship between capital structure and financial performance of China's real estate listed companies. Journal of Finance and Economics, 3(4), 72-76.

García-Teruel, P. J., \& Martínez-Solano, P. (2007). Effects of working capital management on sme profitability. International Journal of Managerial Finance, 3(2), 164-177.

Gill, A., Biger, N., \& Mathur, N. (2011). The effect of capital structure on profitability: Evidence from the United States. International Journal of Management, 28(4), 3-15.

Gocmen, T., \& Sahin, O. (2014). The determinants of bank capital structure and the global financial crisis: The case of Turkey. Journal of Applied Finance and Banking, 4(5), 55-67.

Habib, H., Khan, F., \& Wazir, M. (2016). Impact of debt on profitability of firms: Evidence from non-financial sector of Pakistan. City University Research Journal, 6(01), 70-80.

Hall, M., \& Weiss, L. (1967). Firm size and profitability. The Review of Economics and Statistics, 49, 319-331.

Hammes, K., \& Chen, Y. (2004). Performance of the Swedish real estate sector 1998-2002. Working Papers in Economics 124, University of Gothenburg, Department of Economics.

Handoo, A., \& Sharma, K. (2014). A study on determinants of capital structure in India. IIMB Management Review, 26, 170-182.

Herciu, M., Ogrean, C., \& Belascu, L. (2011). A Du Pont analysis of the 20 most profitable companies in the world. Presented in 2010 International Conference on Business and Economics Research.

Himmelberg, C. P., Hubbard, R. G., \& Palia, D. (1999). Understanding the determinants of managerial ownership and the link between ownership and performance. Journal of Financial Economics, 53(3), 353-384.

Irawan, A., \& Faturohman, T. (2015). A study of liquidity and profitability relationship: evidence from Indonesian Capital Market. Paper presented at the Proceedings of $31^{\text {st }}$ The IIER International Conference.

Jensen, M. C. (1986). Agency costs of free cash flow, corporate finance, and takeovers. The American Economic Review, 76(2), 323-332.

Jensen, M. C., \& Meckling, W. H. (1976). Theory of the firm: Managerial behavior, agency costs and ownership structure. Journal of Financial economics, 3(4), 305-360.

Jorgenson, D. W., Ho, M. S., \& Samuels, J. D. (2011). Information technology and US productivity growth: Evidence from a prototype indus- try production account. Journal of Productivity Analysis, 36(2), 159-175.

Kebewar, M. (2012). The effect of debt on corporate profitability: Evidence from French service sector. Brussels Economic Review, 56(1), 43-59.

Lazaridis, I., \& Tryfonidis, D. (2006). Relationship between working capital management and profitability of listed companies in the Athens stock exchange. Journal of Financial Management and Analysis, 19(1).

Lewellen, J. (2004). Predicting returns with financial ratios. Journal of Financial Economics, 74, 209 235.

Lun, Y. H. V., \& Quaddus, M. A. (2011). Firm size and performance: A study on the use of electronic commerce by container transport operators in Hong Kong. Expert Systems with Applications, 38(6), 7227-7234.

Margaritis, D., \& Psillaki, M. (2007). Capital structure and firm efficiency. Journal of Business Finance \& Accounting, 34(9-10), 1447-1469.

Modigliani, F., \& Miller, M. H. (1963). Corporate income taxes and the cost of capital: A correction. The American Economic Review, 53(3), 433-443.

Myers, S. C. (1984). The capital structure puzzle. The Journal of Finance, 39(3), 574-592.

Myers, S. C., \& Majluf, N. S. (1984). Corporate financing and investment decisions when firms have information that investors do not have. Journal of Financial Economics, 13(2), 187221.

Ofek, E. (1993). Capital structure and firm response to poor performance: An empirical analysis. Journal of Financial Economics, 34(1), 3-30.

Panigrahi, A. K. (2013). Relationship between inventory management and profitability: An empirical analysis of Indian cement companies. Asia Pacific Journal of Marketing \& Management Review, 2(7), 107-120.

Ramadan, I. Z. (2013). Debt-performance relation. Evidence from Jordan. International Journal of Academic Research in Accounting, Finance and Management Sciences, 3(1), 323-331.

Rao, N. V., Al-Yahyaee, K. H. M., \& Syed, L. A. (2007). Capital structure and financial performance: Evidence from Oman. Indian Journal of Economics and Business, 6(1).

Saleem, Q., \& Rehman, R. U. (2011). Impacts of liquidity ratios on profitability. Interdisciplinary Journal of Research in Business, 1(7), 95-98.

Şamiloğlu, F., Öztop, A. O., \& Kahraman, Y. E. (2017). The determinants of firm financial performance: Evidence from Istanbul Stock Ex- 
change (BIST). IOSR Journal of Economics and Finance (IOSR-JEF), 8(6-1), 62-67.

San, O. T., \& Heng, T. B. (2013). Factors affecting the profitability of Malaysian commercial banks. African Journal of Business Management, 7(8), 649-660.

Schwarz, G. E. (1978). Estimating the dimension of a model. Annals of Statistics, 6(2), 461-464.

Shubita, M. F., \& Alsawalhah, J. M. (2012). The relationship between capital structure and profitability. International Journal of Business and Social Science, 3(16), 104-112.

Stiroh, K. J. (2002). Information technology and the US productivity revival: What do the industry data say? American Economic Review, 92(5), 1559-1576.

Sufian, F., \& Habibullah, M. S. (2009). Determinants of bank profitability in a developing economy: Empirical evidence from Bangladesh. Journal of Business Economics and Management, 10(3), 207-217.

Sukpanich, N. (2007). Intra-regional sales and performance. In A. M. Rugman(Ed.), Regional Aspects of Multinationality and Performance (Research in Global Strategic Management, Vol. 13) (pp. 317-336). Bingley: Emerald Group Publishing Limited.
Tangen, S. (2003). An overview of frequently used performance measures. Work study, 52(7), 347354.

Titman, S., \& Wessels, R. (1988). The determinants of capital structure choice. The Journal of Finance, 43(1), 1-19.

Tong, T. T., \& Diaz, J. F. (2017) Determinants of banks' capital structure: Evidence from Vietnamese commercial banks. Asian Journal of Finance and Accounting, 9(1), 261-284.

Toy, N., Stonehill, A., Remmers, L., Wright, R., \& Beekhuisen, T. (1974). A comparative international study of growth, profitability, and risk as determinants of corporate debt ratios in the manufacturing sector. Journal of Financial and Quantitative Analysis, 9(5), 875-886.

Vătavu, S. (2015). The impact of capital structure on financial performance in Romanian listed companies. Procedia Economics and Finance, 32, 1314-1322.

Whittington, G. (1980). Some basic properties of accounting ratios. Journal of Business Finance \& Accounting, 7(2), 219-232.

Williamson, O. E. (1988). Corporate finance and corporate governance. The Journal of Finance, 43(3), 567-591. 